\title{
Li-per-els[i] o la despronominalització del clític datiu en català: un fenomen incipient
}

\author{
$L i$ instead of $e l s[i]$ or the depronominalization of the dative clitic in Catalan: \\ an emerging phenomenon
}

Anna Pineda

Universitat Pompeu Fabra. anna.pineda@upf.edu

Received: 06/05/2018. Accepted: 02/08/2018

Resum: L'objectiu d'aquesta contribució és estudiar un fenomen d'aparició recent en llengua catalana que, a priori, sembla contradir els fonaments de la cohesió referencial. Es tracta del sorgiment, en català, d'un fenomen paral·lel al que en la tradició lingüística de l'espanyol s'ha convingut a anomenar le-por-les, i que en català anomenem li-per-els[i]. Es tracta de l'ús del clític datiu singular en la duplicació d'un objecte indirecte plural, com en $L i_{\text {[sg.] }}$ he donat el llibre als nens $s_{\text {[p.]. }}$. Veurem que aquest fenomen, cada cop més present en parlars com els valencians i els de l'àrea de Barcelona, es pot caracteritzar com un cas de despronominalització del pronom feble de datiu, fruit de la generalització de la duplicació de clític datiu que s'ha produït, justament, en aquestes àrees. A mesura que la duplicació esdevé sistemàtica, li perd el seu estatus de pronom anafòric $i$, desproveït de qualsevol traça de concordança, esdevé un mer marcador gramatical en el verb, una mena d'afix que assenyala la presència d'un argument prominent, l'objecte indirecte. Presentem una varietat de factors que poden crear les condicions en les quals aquest afix verbal (el clític datiu no concordant) esdevé necessari. Finalment, proporcionem una anàlisi formal basada en l'assumpció que els clítics duplicadors són la realització d'un nucli aplicatiu, responsable d'introduir l'OI en l'estructura.

Paraules clau: duplicació de clític; datiu; objecte indirecte; aplicatiu; concordança; català; variació dialectal.

\footnotetext{
Abstract: This contribution aims to study a phenomenon which has recently emerged in Catalan and which seems to contradict the foundations of referential cohesion. It is a phenomenon parallel to what in the Spanish linguistic tradition has been dubbed lefor-les, that is to say, the use of a singular dative clitic when doubling a plural indirect object, as in $L i_{\text {[sg.] }}$ he donat el llibre als nens ${ }_{\text {[pl.] }}$ 'I have given the book to the kids'. I

》Pineda, Anna. 2018. "Li-per-els[i] o la despronominalització del clític datiu en català: un fenomen incipient”. Quaderns de Filologia: Estudis Lingüistics XXIII: 247-281. doi: 10.7203/qf.23.13530
} 
will show that this phenomenon, which is more and more present in Valencian varieties as well as in the Catalan spoken in the area of Barcelona, can be accounted for as an instance of depronominalization of the dative clitic pronoun, as a result of the generalization of dative clitic doubling which has occurred, precisely, in the mentioned varieties. As doubling becomes systematic, $l i$ looses its status of anaphoric pronoun and, deprived of any trace of agreement, it becomes just a grammatical marker in the verb, a sort of verbal affix whose sole function is to indicate the presence of a prominent argument in the sentence, the indirect object. I present a variety of factors that may create the conditions where such a verbal affix (the non-agreeing dative clitic) becomes necessary. Finally, I provide a formal analysis based on the assumption that doubling clitics are the realization of an applicative head, which is responsible of introducing the IO in the structure.

Keywords: clitic doubling; dative; indirect object; applicative; agreement; Catalan; dialectal variation. 


\section{Presentació del fenomen li-per-els[i]}

L'objectiu d'aquesta contribució és estudiar un fenomen d'aparició recent en llengua catalana situat a les interfícies de la sintaxi, la semàntica i la pragmàtica i que, a priori, sembla contradir els fonaments de la cohesió referencial. Es tracta del sorgiment, en català, d'un fenomen paral·lel al que en la tradició lingüística de l'espanyol s'ha convingut a anomenar le-por-les, és a dir, l'ús del clític datiu singular en la duplicació d'un objecte indirecte (1) ${ }^{1}$ :

(1) Ya le $e_{[\mathrm{sg}]}$ dije a los niños ${ }_{[\mathrm{pl]}]}$ que vinieran.

Si en el cas de l'espanyol aquest canvi va començar a ser productiu a principis del segle XX i actualment es considera que «podria llegar a convertirse en la norma» (Huerta Flores, 2005: 186), en el cas del català sembla que és darrerament que, en registres col-loquials, comencen a ser força freqüents seqüències com la de (2), en que el pronom li és utilitzat en comptes de elsi (català central) o en comptes de els (valencià) ${ }^{2}$ :

$\boldsymbol{L i}_{[\mathrm{sg]}}$ vaig dir als clients $_{[\mathrm{pl]}}$ que tancaríem. (parla espontània, català central, dona jove, Barcelona)

\footnotetext{
${ }^{1}$ Ja fa dècades que la manca de concordança de nombre en la duplicació clític de datiu en espanyol es va començar a detectar, documentar i analitzar. En són exemples els treballs de Cuervo (1907/1955), Casares (1918: 107-120), Sturgis (1927), FernándezSoriano (1999) o Huerta Flores (2005), entre d'altres. Si bé el fenomen és present en tot el domini, aquests treballs destaquen que està més estès a Amèrica que a Europa -a tall d'exemple, l'estudi de corpus de Huerta Flores (2005: 170) constata que en l'espanyol de Mèxic hi ha le-por-les en el $57 \%$ de les ocurrències de V-OI, enfront d'un $43 \%$ d'ocurrències amb concordança; és a dir, la manca de concordança és majoritària. ${ }^{2}$ Tot i que segurament no té cap valor representatiu, reproduïm en (i) un exemple del català antic que sembla reflectir un cas de pèrdua de concordança entre l'OI i el clític datiu duplicador. Sens dubte, resseguir amb precisió l'evolució d'aquest fenomen en l'eix diacrònic de la llengua és un repte pendent (per a una aproximació als clítics datius plurals del català antic, vg. Ribera, 2019). En concret, caldrà veure si exemples del català antic com el de (i) són gaire freqüents. Sabem que en espanyol antic aquest fenomen ja existia (Casares, 1918: 114; Cuervo, 1955: 346-349; Flórez, 1967: 64; Huerta Flores, 2005: 166), encara que no es va estendre de manera destacable fins a l'etapa moderna.

(i) E li havia tolt lo castel e la vila d'Alvero e bé $x \cdot$ millia kafizes de pa qui eren seus, oltra lo mal que $i_{[\mathrm{sg}]}$ havia feyt als chrestians e als serraÿns ${ }_{[\mathrm{pl}]} d^{\prime}$ 'Alvero. (Llibre dels fets del rei en Jaume, Fol. 7r, lín. 25, segle XIV)
} 
Aquest fenomen (en el cas de l'espanyol) ha estat caracteritzat per Company (2003: 237) com un cas de despronominalització del pronom feble de datiu, fruit de la generalització de la duplicació de clític datiu. En altres paraules, el fet que la duplicació de l'objecte indirecte (OI) a través d'un clític datiu esdevingui gairebé sistemàtica en espanyol (3a) i també en moltes varietats del català (3b) (Todolí, 2002; Pineda, 2013, 2016) fa que els clítics le / li perdin el seu estatus de pronom anafòric ${ }^{3}$ i passin a ser un mer marcador gramatical en el verb, una mena d'afix que se situa en el nucli de la predicació (el verb) i assenyala la presència d'un argument prominent, l'OI:

\section{(3) a. Le di el libro a María. \\ b. Li vaig donar el llibre a la Maria.}

En termes de reanàlisi, doncs, el pronom feble de datiu hauria passat de ser un pronom anafòric a ser un marcador de concordança verb-objecte (concretament verb-objecte indirecte) (3), de manera que es creen les condicions perquè la concordança deixi de ser necessària.

Formalment, els pronoms febles datius que dupliquen un OI han estat analitzats com la realització d'un nucli aplicatiu (Cuervo, 2003; Pineda, 2013, 2016), és a dir, del nucli que permet introduir i legitimar els OI en l'estructura (Pylkkänen, 2002/2008). En aquest article adoptem aquest enfocament teòric, amb l'objectiu últim de donar compte del que ocorre a (2). Es tracta, doncs, d'explicar com és que l'estat de coses de (3), és a dir, la sistematizació de la duplicació de clític, acaba possibilitant que les llengües en estudi facin un pas més enllà $i$ obviïn la concordança de nombre entre el clític i l'OI i creïn el que sembla un contrasentit des del punt de vista de la cohesió referencial.

L'article s'estructura de la manera següent. En primer lloc oferim una caracterització de la duplicació de clític datiu en català (secció 2). A continuació, ens endinsem en el fenomen del li-per-els[i], que suposa, justament, fer un pas més enllà respecte de la generalització dels clítics datius duplicadors. Aquests elements passen a perdre la concor-

\footnotetext{
${ }^{3}$ Tal com descriu Rigau (1980), l'ús dels pronoms clítics és una operació de substitució fonamentada en una relació anafòrica: el clític és més reduït que el seu antecedent, i això permet agilitzar el discurs. A més d'aquesta funció facilitadora, Todolí (2002: § 6.3.1) hi afegeix la funció cohesiva, atès que els clítics són un mecanisme bàsic de cohesió textual, necessaris per a la bona formació del text.
} 
dança amb l'argument al qual dupliquen: tot i tractar-se, en el cas de la llengua catalana, d'un fenomen marcadament incipient $i$, per tant, molt poc assentat, mirem de descriure'n l'abast, els contextos d'aparició i les incompatibilitats o restriccions (secció 3). A continuació, presentem l'anàlisi formal, basada en el nucli aplicatiu, que permet donar compte de la coaparició d'un clític datiu duplicador i l'OI que és duplicat, i també del fet que el clític duplicador pugui perdre la concordança (secció 4). Conjuntament, les seccions 3 i 4 permeten exposar com, des del pla descriptiu però també des del pla més teòric, l'estat de coses de la llengua ha pogut conduir a l'emergència de l'anomenat li-per-els [i] en català. Finalment, presentem les conclusions de l'article (secció 5).

\section{La duplicació de clític datiu en català: caracterització del fenomen i distribució dialectal}

És ben conegut que els clítics de datiu en català s'empren per substituir un objecte indirecte absent en l'oració però que es pot recuperar perquè ha aparegut anteriorment en el discurs (4). Així mateix, també trobem els anomenats clítics de represa, que serveixen per recuperar, dins la matriu oracional, un element dislocat (5), ja sigui al marge esquerre (sinislocació) o al marge dret (dextralocació):

(4) Va venir la perruquera i li vaig donar el que volia.

(5) a. A la meva perruquera, li explico tot el que em passa.

b. Li explico tot el que em passa, a la meva perruquera.

En tots dos casos, la funció referencial del clític és òbvia. La seva presència ens permet recuperar l'antecedent en qüestió, esmentat anteriorment en el discurs i per tant viu en la memòria de l'emissor i el receptor, o bé desplaçat als marges de la matriu oracional per aconseguir un efecte pragmàtic concret relacionat amb l'estructura informativa (Vallduví, 2002: § 4.3.4, § 4.3.5, § 4.5).

Tanmateix, la utilització dels clítics que ens interessa aquí no és cap d'aquestes dues. Ens interessen els casos de duplicació de clític autèntica, adoptant el terme de Vallduví (2002: §4.3.6), això és, els casos que, en termes tradicionals, serien qualificats de pleonasme, atès que en el si d'una mateixa oració coapareixen un clític de datiu i un sintagma 
coreferencial lèxicament realitzat en la seva posició canònica (6), i no pas en una posició desplaçada com a (5):

(6) a. Li vaig donar el paquet al carter.

b. Els [i] vaig donar el paquet als treballadors. (català central)

c. Els vaig donar el paquet als treballadors. (valencià)

Més endavant, a la secció 4, ens centrarem en els casos en què el pronom $l i$ apareix duplicant un OI plural, com el que presentàvem a (2). Per ara, convé definir els paràmetres que caracteritzen la duplicació de clític més generalitzada, la que manté la concordança amb 1'OI duplicat (6).

La duplicació de clític té una extensió diferent segons els tipus de predicats (com ja apuntà, per exemple, Solà, 1994: 253), però també segons les varietats dialectals (i també idiolectals). Precisament, cal diferenciar les estructures datives que en tot el domini solen construir-se amb duplicació de clític, i les que només admeten el clític en alguns parlars.

\subsection{Predicats amb duplicació de datiu (quasi)obligatòria}

En el primer grup, el de casos de duplicació de datiu més generalitzada, hi trobem els datius benefactius, que designen un participant afectat o interessat en el predicat verbal (7). Dins dels datius benefactius hi trobem un subtipus que correspon als datius possessius, cas en què el benefici o l'afectació prové de la relació de possessió que el datiu estableix amb el subjecte d'un verb intransitiu inacusatiu (8) o amb el complement directe d'un verb transitiu (9):

(7) Li pintaran un quadre a en Pere.

(8) Li ha sortit una erupció a la Maria.

(9) Li han destrossat la casa a en Josep.

En aquests casos, arreu del domini hi ha una preferència clara per la duplicació. Tal com assenyala Todolí (2002: §6.5.5.3b), si no hi hagués duplicació els complements introduïts per a (Pintaran un quadre a en 
Pere, Han destrossat la casa a en Josep, etc.) no s'interpretarien com a complements afectats o interessats (o posseïdors) sinó que tindrien una interpretació «semblant a la els complements circumstancials i, més concretament, a la dels SP introduïts per la preposició per a», en el cas dels datius benefactius (Pintaran un quadre per a en Pere), i semblant «a la dels complements genitius introduïts per la preposició de», en el cas dels datius possessius (Han destrossat la casa d'en Josep).

Sobre aquests datius possessius, Bel (2002: §2.2.4.1b) constata que «el que sembla [...] més inqüestionable és que el valor de possessió és aportat pel clític», de manera que si el clític és absent no només es perd el sentit de possessió sinó que l'oració esdevé inacceptable ${ }^{*}$ He trobat la joguina a l'Enric). Tanmateix, pensem que és més acurada l'observació de Todolí, en el sentit que aquestes oracions sense doblat també són bones però presenten una diferència interpretativa (vg. també Pineda, 2016: $\S 2.2 .2 .5)^{4}$.

En aquest primer grup de predicats amb duplicació (quasi)obligatòria hi ha també els predicats amb datius experimentadors. Són verbs que designen activitats psicològiques com agradar, molestar, interessar o doldre i verbs pseudoimpersonals com passar, ocórrer, caldre o fer falta. Todolí (2002: $§$ 6.5.5.3c) apunta que la duplicació de datiu és «obligatòria o quasi obligatòria en la major part dels contextos, i no hi ha gaires diferències entre els dialectes que presenten una duplicació forta i els dialectes que es caracteritzen per una duplicació feble». El fet que aquests verbs es construeixin generalment amb un OI amb característiques de subjecte (posició preverbal, animat, tema discursiu) i un subjecte amb característiques de complement directe (posició post-

\footnotetext{
${ }^{4}$ D'altra banda, en els casos de possessió inalienable (per exemple, quan allò posseït és una part del cos, com en Li han trencat la cara a la Maria), tant Todolí com Bel noten que l'opció sense clític no està disponible (*Vaig tallar el dit a la Maria). Tanmateix, aquesta generalització no és pas infal·lible, i és que oracions com Aquells brètols han trencat la cara a la Maria, En aquell país tallen les mans als acusats de robatori o Primer van tallar les ungles a la Maria i després a mi són acceptables. És especialment il·lustratiu l'exemple (i), extret de la premsa escrita, i en el qual l'entrevistat explica que en el seu llibre pretén explicar el funcionament de la mentalitat dels alemanys:

(i) Titular: He volgut explicar com funciona el cap als alemanys Cos: [...] intento explicar com funciona el cap als alemanys, una gent que no només manen a Alemanya, sinó que també manen a Europa. (entrevista a Martí Anglada, El Punt Avui, 2 abril 2014).
} 
verbal, inanimat, rema discursiu), com veiem en (10) i (11), dibuixa un paral·lelisme clar amb les construccions amb dislocació, com la de (5a), on la duplicació és obligatòria, fet que explica que també ho sigui en aquestes construccions:

(10) A la Sara li agrada la novel-la d'intriga

(11) A la teva filla no sé què li passa

Hi ha, però, matisos pel que fa a aquesta obligatorietat de la duplicació amb aquests predicats, perquè les propietats referencials de l'OI i del subjecte hi influeixen, tal com exposa Todolí (2002: § 6.5.5.3c). Amb els verbs psicològics, les condicions més favorables per a la duplicació consisteixen en un OI definit i temàtic i un caràcter indefinit i remàtic de l'altre argument en joc, en aquest cas el subjecte, la qual cosa explica per exemple l'obligatorietat del clític en una oració amb un subjecte indefinit i remàtic i un OI definit i temàtic (12) en oposició a l'opcionalitat en una oració amb un subjecte definit i temàtic i un OI indefinit i remàtic (13):

(12) a. ¿Saps què *(li) agrada a en Joan?

b. ¿Què *(li) ha interessat més a la teva professora?

(13) a. La pel-lícula de l'altre dia no (li) va agradar a ningú.

b. Aquests temes (li) interessen a tothom.

Amb els verbs pseudoimpersonals, en canvi, la duplicació és (quasi)obligatòria fins i tot quan el subjecte és definit i temàtic i l'OI és indefinit i remàtic (14). Això es deu, tal com explica Todolí (2002: § 6.5.5.3c), al fet que «els factors referencials que afavoreixen la duplicació de clític es troben més accentuats en aquests verbs i funcionen més com una norma que no pas com una tendència»: cal tenir present que el subjecte d'aquests verbs existeix en la mesura que hi ha un OI experimentador capaç de suportar-lo, la qual cosa implica que el subjecte sigui, de fet, més indefinit i més remàtic que l'OI.

Aquests accidents domèstics ${ }^{\text {??** }}$ (li) passen a tothom 


\subsection{Predicats amb duplicació de datiu opcional}

Hem descrit fins ara el primer grup de predicats, amb el qual la duplicació és, arreu del domini, molt general o gairebé sistemàtica. Hi ha, però, un segon grup de verb amb els quals la duplicació és clarament opcional i depèn fortament de la varietat dialectal o fins i tot idiolectal. Aquest grup inclou els OI meta que trobem en les construccions ditransitives del tipus donar(-li) una cosa a algú. Així, una oració com (15) és completament bona en diverses subvarietats del català central (per exemple el barceloní) i en valencià, entre d'altres.

\section{Li vaig donar la foto a ma mare.}

Aquestes preferències dialectals per la duplicació en oracions com (15) també les detecta Todolí (2002: §6.5.5.3), d'acord amb la qual la duplicació de l'OI amb verbs ditransitius com donar no és pas obligatòria, si bé hi ha una tendència a fer-l'hi, especialment en determinats dialectes com el valencià i el barceloní. En canvi, el fenomen és més esporàdic en la major part del català nord-occidental i en la resta del bloc oriental. En aquest sentit, Todolí distingeix els dialectes amb duplicació forta (els primers) i els dialectes amb duplicació feble (els segons). Per exemplificar-ho, reporta que la duplicació pronominal «no apareix amb la mateixa freqüència en un autor d'origen oriental com Quim Monzó [...] (del qual aportem exemples amb duplicació de complement indirecte i sense [...]) que en un autor d'origen valencià com Francesc Mira (que duplica sistemàticament)» (Todolí, 2002: §6.5.5.3) .

Amb tot, cal tenir present, com recorda Todolí (2002: §6.5.5.3d), que la duplicació dels datius meta no està lliure de condicionants, sinó

\footnotetext{
${ }^{5}$ Convé assenyalar que, en general, l'OI meta només pot duplicar-se (més sistemàticament en els dialectes amb duplicació forta i més opcionalment en els de duplicació feble) si és [+animat] (i generalment [+humà]), ja que si l'OI és [-animat] s'acosta més als locatius o datius inanimats, per als quals la possibilitat de duplicació és pràcticament inexistent. Cal dir, però, que en dialectes amb duplicació forta com el valencià el fenomen de la duplicació comença a traspassar la frontera de l'animacitat i ja no són gaire estranyes oracions com (i). Tampoc no són gens estranyes, en parlars com el valencià i el barceloní, oracions com (ii) -per a una aproximació a la duplicació d'OI "no prototípics”, vg. Pineda (2016: \$2.2.3).
}

(i) Li va pegar un colp a la porta.

(ii) Li dones massa importància a aquesta qüestió. 
que depèn de les característiques sintàctiques (p. ex. és més freqüent amb els triargumentals que amb els biargumentals $)^{6}$ i pragmàtiques de la construcció (incloent-hi la referencialitat dels complements). Així, en el cas dels verbs ditransitius la duplicació és més probable si l'OD és indefinit i remàtic i l'OI és definit i temàtic (16) -i, de fet, en els dialectes amb duplicació forta, és a dir, amb una tendència molt generalitzada a fer-l'hi, aquesta darrera oració sense clític serà rebutjada. En canvi, es pot prescindir de la duplicació quan les característiques pragmàtiques dels components canvien (17):

\section{Què li diràs a la teva mare?}

\section{Això no ho direm a ningú.}

Com veurem més endavant, propietats com la referencialitat també són rellevants a l'hora d'explicar l'emergència del fenomen li-perels [i] (secció 4).

En resum, la duplicació d'un OI meta és optativa en català, però en diversos dialectes aquest fenomen guanya cada cop més sistematicitat. A més, s'observa arreu del domini una major tendència a la duplicació de datiu en el parlar de les generacions joves, que són també les generacions que introdueixen amb més força el fenomen incipient del li-perels [i], del qual parlarem a la secció 4.

Aquesta sistematització de la duplicació d'OI meta no és pas un fenomen estrany si ens fixem en l'estat de coses de l'àmbit romànic. L'opcionalitat de la duplicació de datiu amb els arguments datius caracteritza també l'espanyol (18), on aquest fenomen està cada cop més generalitzat. Tot i que és ben possible que el contacte i la pressió de l'espanyol hagi tingut a veure amb l'extensió del fenomen en català, convé no perdre de vista que la duplicació de l'OI és un opció també present en altres llengües romàniques, com el romanès (19) i varietats de l'italià col·loquial (20). Fins i tot, altres llengües neollatines presenten un patró molt més generalitzat encara, per exemple en l'espanyol del Río de la Plata, de Xile i de Caracas es dupliquen sempre tots els arguments

\footnotetext{
${ }^{6}$ Pérez Saldanya (1996) apunta que això es pot deure al fet que en contextos biargumentals l'OI agafa característiques d'OD, i precisament la duplicació és un tret més característic de la funció d'OI.
} 
datius (i fins i tot alguns acusatius, com en La vi a María) (Parodi, 1998; Senn, 2008; Pujalte, 2009), o per exemple també el trentí (21), on d'acord amb Cordin (1993) la duplicació de datiu és obligatòria:

(18) Juan (le) dio un regalo a su sobrina.

$\begin{array}{lllll}\text { Mihaela (ii) } & \text { trimite } & \text { Mariei } & o & \text { scrisoare. } \\ \text { Mihaela CL.DAT } & \text { envia } & \text { Maria.DAT } & \text { una } & \text { carta }\end{array}$

'La Mihaela (li) envia una carta a la Maria'

(Diaconescu \& Rivero 2007: 213)

$\begin{array}{lllll}\text { (Gli) ho dato } & \text { il } & \text { regalo a } & \text { Mario. } \\ \text { CL.DAT have given the present to } & \text { Mario }\end{array}$

'(Li) ha donat el regal al Mario.'

(21) a. *(Ghe) dago el regal al Mario

'Li donaré el regal al Mario'

b. *(Ghe) dago na nosela a l'orso

'Li donaré un cacauet a l'ós'

c. *(Ghe) dago en buton ala machina

'Li donaré una empenta al cotxe'

d. *(Ghe) dago el regal a qualchedun

'Li donaré el regal a algú'

(Cordin 1993: 130-131)

En definitiva, en la generalització de la duplicació de clític en català s'hi pot veure segurament el reflex de la influència de l'espanyol (suggereix aquesta possibilitat, per exemple, Todolí (2002: §6.5.5.3d)). Alhora, però, cal tenir en compte que la duplicació és un fenomen marcadament estès a la Romània. És possible, doncs, que en el cas català hi hagi també un component relacionat amb l'evolució interna de la llengua, i concretament amb la pèrdua de l'estatus de pronom anafòric històricament associat amb els clítics datius, que passen a ser un simple marcador gramatical en el verb, amb la funció d'assenyalar la presència d'un argument prominent, l'OI.

\footnotetext{
${ }^{7}$ També en l'espanyol del País Basc els arguments acusatius es dupliquen, però amb el clític le, atès el leísmo de la regió: Le vi a María, vg. per exemple Urrutia Cárdenas (2003).
} 


\section{Aproximació al fenomen li-per-els[i]}

Un cop presentada i descrita la duplicació de clític datiu en català, podem tornar al fenomen que va un pas més enllà, l'anomenat li-per-els [i]. Abans de fer cap apreciació, però, volem matisar que les observacions que fem es basen en els exemples que hem anat recollint els darrers anys a partir de les fonts següents, amb representació de diversos dialectes, principalment el català central i el valencià: la parla espontània de persones del nostre entorn, els mitjans de comunicació orals, la premsa escrita i alguns llibres. Tanmateix, caldrà sens dubte reforçar aquesta aproximació preliminar amb un estudi aprofundit del fenomen, ja sigui amb entrevistes a informants o a partir de corpus extensos que permetin obtenir dades de freqüència rellevants $i$ objectivables, $i$ controlar variables com ara l'edat o el dialecte. A l'espera que es pugui dur a terme un estudi tal en el futur, ens disposem a caracteritzar el fenomen a partir de les dades que hem pogut recollir.

\subsection{Els tipus de predicats}

Si ens guiem pels dos grans grups de predicats, els que presenten duplicació de datiu (quasi)obligatòria i els que presenten duplicació de datiu opcional, cal dir que el fenomen li-per-els[i] no sembla fer una distinció entre aquests dos grups, sinó que en trobem exemples en ambdós casos, i de fet són més abundants els exemples corresponents als predicats amb duplicació teòricament opcional, com donar.

Proporcionem primer diversos exemples amb predicats que exigeixen la duplicació, com ara els verbs psicològics agradar (22) i molestar (23), o el pseudoimpersonal passar (24):

(22) a. Quin tipus de dona $\boldsymbol{l i}_{[\mathrm{sgl}}$ agrada més als homes ${ }_{[\mathrm{pl]}]}$ ? (Catalunya Diari, $15 / 11 / 2016)$

b. Si pregunta què $\boldsymbol{l i}_{[\mathrm{sg}]}$ agrada als nois ${ }_{[\mathrm{pl]}}$ és que vol saber què li agrada als nois. (fòrum, Nació Digital-secció Adolescents.cat, 23/05/2017) 
"El que en el fons $\boldsymbol{l}_{[\mathrm{sg}]}$ molesta als socialistes ${ }_{[\mathrm{pl]}]}-$ Ha conclòs Alfonso Grau- és que hàgem posat en marxa un Bioparc magnific, que no ha suposat un desembossament milionari per part del consistori". (Valencia.es, portal de notícies de l'Ajuntament de València, 29/01/2010)

(24) Què li $i_{\text {[sg] }}$ deu passar als micos ${ }_{\text {[pl] }}$ de Gibraltar? (Pilar Rahola, RAC1, 2017)

Com avançàvem, són encara més abundants els exemples de li-perels [i] amb predicats amb els quals la duplicació és en principi opcional. En donem alguns exemples amb els verbs donar (25), cedir (26) i proporcionar (27), que expressen la transferència d'un objecte físic, $\mathrm{i}$ amb el verb dir (28), que expressa en aquest cas la transferència d'un objecte mental:

(25) a. El nou líder del PSC creu que la lògica dels resultats del 24-M portava el seu partit a l'oposició | Admet tensions internes sobre el pacte de govern amb ERC, $i$ el defensa per la visibilitat que $\boldsymbol{l}_{[\mathrm{sg}]}$ dóna als socialistes $_{[\mathrm{pl]}]^{\circ}}$ (Nació Digital, edició Lleida, 21/06/2015)

b. També va ser professor d'Història del Periodisme a l'Autònoma de Barcelona, quins consells $\boldsymbol{l}_{[\mathrm{sg}]}$ donava als seus alumnes ${ }_{[\mathrm{pl]}}$ per a ser millor professional? (Catalunya Press, 01/04/2016)

c. La llet de fórmula està sent molt rebutjada, com si fos un invent tòxic que se $\boldsymbol{l i}_{\text {[sg] }}$ dona als nens ${ }_{\text {[pl] }}$ (El Periódico, 10/03/2018)

d. Ui, pipes de carabassa. Això és lo que $\boldsymbol{l i}_{[\mathrm{sg}]}$ donen als pardals ${ }_{[\mathrm{pl}]}$ ! (parla espontània, valencià, home jove, Alt Vinalopó)

e. Per què, tal com va dir Mahatma Gandhi, el grau de civilització d'un poble és mesura en el tracte que $\boldsymbol{l i}_{[\mathrm{sg}]}$ dóna als animals $\boldsymbol{[ p \mathrm { pl }}$ (Tot Sant Cugat, 2017)

f. Som el club del món que més valor $\boldsymbol{l i}_{[\mathrm{sg}]}$ dona als futbolistes formats a casa seva $_{[\mathrm{pl]}]}$ (El País, 15/11/2017)

(26) Qui és el guapo dels set [diputats electes] que $\boldsymbol{l i}_{\text {[sg] }}$ cedeix la seva cadira als comuns $\boldsymbol{s p l ]}_{\text {? }}$ ? (Jofre Llombart, RAC1, 2018)

(27) Cada vegada que pose els peus en un jutjat qualsevol, em costa pair tanta superficialitat; tant de retard burocràtic; el jutge maleducat amb pressa i sense interès; [...]; la nul-la preparació del judici, o l'estafa que $\boldsymbol{l i}_{\text {[sg] }}$ proporciona als seus clients $_{[\mathrm{pll}]}$. (Diari La Veu, 08/09/2017) 


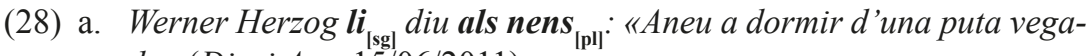
da» (Diari Ara, 15/06/2011)

b. Finalment, Oriol Junqueras ha exposat al presentador que "vostè s'imagina alguna democràcia en la qual un govern $\boldsymbol{l i}_{\text {[sg] }}$ diu als propietaris $_{[\mathrm{pl]}]}$ d'una empresa que no són ells els que han de decidir sobre la seu social d'una empresa?". (E-notícies, 18/10/2017)

c. «Si algú pretén a continuació (dels comicis) incomplir la llei, el govern $\boldsymbol{l i}_{[\mathrm{sg}]]}$ diu als espanyols ${ }_{[\mathrm{pl]}}$ que vetllarà pel seu compliment com fins ara, en particular si algú vol vulnerar la sobirania nacional», ha sentenciat. (Vilaweb, 18/06/2015)

d. Les 4 coses que el Papa li ${ }_{[\mathrm{sg}]}$ diu als pobres ${ }_{[\mathrm{pl]}]}$ (Acció Catòlica Obrera, http://acocat.org, 2017)

Hom podria pensar que el fenomen de la pèrdua de concordança del clític duplicador s'hauria de donar amb molta més freqüència amb aquells predicats amb els quals la duplicació ja és sistemàtica arreu del domini. Les dades, però, no corroboren això, sinó que indiquen que el fenomen del li-per-els [i] apareix amb els diversos tipus de predicats, i de fet és més freqüent amb els de duplicació opcional, com donar. Pensem que això es deu al fet que els dialectes en els quals aquest fenomen comença a veure's amb una certa representativitat, això és, el català central (sobretot de l'àrea d'influència de Barcelona) i el valencià, són dialectes en els quals la duplicació, com ja apuntava Todolí (2002), és pràcticament obligatòria no només amb els verbs del tipus agradar $\mathrm{o}$ ocórrer, sinó també amb els verbs del tipus donar o dir. A més, si tenim en compte els factors lexicosemàntics que s'han considerat rellevants per al sorgiment d'aquest fenomen en el cas de l'espanyol, constatarem que el que ocorre en català (una freqüència major de la pèrdua de concordança amb verbs del tipus donar, dir que no amb verbs del tipus agradar, ocórrer) és de fet esperable (vg. subapartat 3.4).

Per acabar, cal dir que a aquests dos grans grups de predicats els corresponen estructures diferents que reflecteixen la distinta naturalesa de l'OI (experimentador o beneficiari en un cas, meta o receptor en l'altre), tal com mostrarem amb l'anàlisi formal de la secció 4 .

\subsection{La generalització de la duplicació de datiu: pas previ necessari}

En primer lloc, el fenomen de la manca de concordança del clític datiu representa un pas més enllà respecte de la generalització del clític 
datiu duplicador. És a dir, perquè la pèrdua de concordança es pugui produir en una varietat lingüística, primer s'ha d'haver generalitzat la duplicació de l'OI. Quan es produeix la generalització de la duplicació, té lloc un procés de gramaticalització que fa que el clític es despronominalitzi: en les construccions amb duplicació, com Li he donat el regal al nen, ja no és un pronom, a diferència del que ocorre en una oració del tipus He vist el nen i li he donat el regal, on el clític "representa", "substitueix" un argument datiu amb un referent esmentat prèviament en el discurs. En les oracions amb duplicació, doncs, el clític ja no es pot considerar un pronom superflu que reprodueix l'OI lèxic, és a dir, ja no pot ser interpretat gramaticalment com un pronom. S'ha despronominalitzat $i$, mitjançant la reanàlisi, $s$ 'ha reinterpretat com una marca de concordança en el verb que té la funció d'assenyalar la presència d'un objecte prominent en el SV, l'OI (Huerta Flores, 2005: 170, 172 i ref. allí citades). És a dir, ara el clític simplement indica o anticipa la presència d'un OI i n'assenyala l'estatus especial (topical, prominent, central, d'alta jerarquia). En aquest sentit, per entendre per què l'OI és un objecte prominent, destacat, etc. cal tenir present que, des del punt de vista semàntic, els OI solen ser més rellevants en l'oració que els OD perquè es refereixen prototípicament a éssers humans, i també se solen situar jeràrquicament per sobre dels OD pel que fa al tret de topicalitat (Langacker, 1991: 236-239; Company, 1998: 539-440).

Així doncs, un primer pas necessari per al fenomen que estudiem és la generalització de la duplicació de clític datiu. Com ja hem apuntat, aquesta duplicació és molt sistemàtica en diverses varietats del català, i encara més indiscutiblement en espanyol-són il·lustratives les paraules de Huerta Flores (2005: 166): «El objeto indirecto en el español actual parece haber incorporado como obligatòria la concurrència de un clítico dativo que lo duplica en su misma frase verbal» (vg. també Huerta Flores, 2005: 170).

Un cop s'ha generalitzat la duplicació de datiu, és a dir, un cop s'ha produït la despronominalització del clític datiu, podem entendre que la marca de plural esdevingui innecessària, perquè ja apareix en l'OI lèxic, duplicat. En el fons, és cert que no és tipològicament estrany que els arguments pronominals incorporats al verb tinguin menys contingut fonètic que els corresponents pronoms independents (Bresnan \& Mchombo, 1987: 765). La pèrdua de concordança no és, però, sistemàtica, sinó que hi ha diversos factors que la condicionen. Aquests factors 
han estat molt ben estudiats per a l'espanyol, i a continuació veurem que, en bona mesura, també semblen rellevants per al català.

\subsection{La posició postverbal de l'OI}

Un primer factor que regula la manca de concordança és la posició. Diversos autors han coincidit a assenyalar que és condició necessària per al fenomen le-por-les de l'espanyol la posició postverbal de l'OI (Alcina \& Blecua, 1975: 608; Fernández Ramírez, 1987: 51; Soler, 1992: 66-67; Company, 2003: 238; Ausín \& Fernández-Rubiera, 2017: 104-105) ${ }^{8}$. El requisit de l'ordre V-OI també es constata en català, tal com observem en tots els exemples del català que hem donat fins ara. No hem trobat ni un sol exemple de pèrdua de concordança amb un OI preverbal (és a dir, exemples amb sinislocació) i, de fet, una enquesta amb alguns informants ens permet constatar que, si alterem l'ordre dels exemples de què disposem, obtenim resultats agramaticals:

\section{*Als clients li vaig dir que tancaríem.}

\section{*Als micos de Gibraltar què li deu passar?}

Huerta Flores (2005: 185) apunta que, en el cas de l'espanyol, la precedència de l'OI en aquests exemples ajuda que el parlant «tenga más claro el número del OI», la qual cosa fa que la pèrdua de la concordança sigui més difícil'. A això s'hi suma el fet que els objectes dislocats ocupen una posició clarament topical i són elements discursivament prominents i centrals, de manera que no cal recórrer a cap marca verbal que n'assenyali la centralitat o prominència. Alhora, observem que

\footnotetext{
${ }^{8}$ Però vg. també Huerta Flores (2005: 184) per a una constatació d'una presència incipient del fenomen també quan l'OI és preverbal, en espanyol mexicà; i Soler (1992: 62) per a una constatació similar en altres dialectes, com l'espanyol d'Argentina, el de Xile i el de Caracas. Company (2003: 238) també certifica aquest lleu avenç del fenomen quan l'OI es troba en una posició marcada.

${ }^{9}$ En espanyol, però, es documenten exemples d'aquest tipus amb pèrdua de concordança, com el següent, extret de la premsa (apud Huerta Flores, 2005: 185). Sens dubte, el fet que el fenomen s'estengui fins i tot cap aquests contextos és un indici de com està d'avançat.

(i) A los que hayan leido las noticias a lo largo del año le serán familiares una serie de nombres
} 
(29)-(30) són estructures amb l'OI dislocat, de manera que el clític de fet ja no és duplicador sinó de represa: aquests clítics, en català, no sembla que siguin susceptible de patir la pèrdua de concordança, com tampoc seria possible amb OI dextralocats (31)-(32) ${ }^{10}$ :

*Li vaig dir que tancaríem, als clients. (cf. (2))

*Què li deu passar, als micos de Gibraltar? (cf. (24))

Un cop exposades les consideracions pel que fa a la posició dels OI pel que fa al sorgiment del fenomen li-per-els[i], ens referirem al conjunt de factors lexicosemàntics, sintàctics i pragmàtics relacionats amb el manteniment vs. degradació de les característiques prototípiques de l'OI i, per tant, amb el fenomen que ens ocupa.

\subsection{Factors que causen la degradació lexicosemàntica de l'OI}

Com avançàvem, la posició no és pas l'únic factor que condiciona la possibilitat que es produeixi la manca de concordança. Hi ha un conjunt de factors d'índole diversa (factors lexicosemàntics, sintàctics i pragmàtics) que poden contribuir a debilitar els trets prototípics de l'OI i, per tant, a obstaculitzar la seva codificació ràpida i clara. Segons Huerta Flores (2005: 172), la pèrdua de concordança s'associa, justament, a aquest debilitament de l'OI: un OI degradat ha de buscar un mecanisme per recuperar la seva centralitat i prominència, $i$ aquest mecanisme de rescat és la transformació del clític duplicador en un afix o marca que se situa en el verb i que té la missió d'anticipar i assenyalar la presència de l'OI en l'estructura. En resum, la pèrdua de la concordança sembla que es pot associar a un seguit de factors que, per una raó o altra, dificulten una codificació ràpida i clara de l'OI i el degraden.

La degradació de l'OI pot ser de tipus lexicosemàntic. Així, si un OI prototípic és [+humà/animat], [+definit], [+volitiu], etc., podem preveure que els OI que es refereixen a entitats situades a la perifèria de la categoria OI (és a dir, entitats mancades de trets tals com la humanitat o animacitat, la individuació i concreció, la volició, la definició, l'activitat i l'energia) seran més propenses a desencadenar la manca de

\footnotetext{
${ }^{10}$ Agraïm a un revisor anònim els seus comentaris en aquest sentit.
} 
concordança. Estudis de corpus com el de Huerta Flores (2005: 173) per a l'espanyol de Mèxic permeten concloure, efectivament, que la pèrdua de concordança és proporcionalment més freqüent amb OI referits a entitats inanimades que no amb OI humans/animats ${ }^{11}$. La idea que el caràcter [-humà] de 1'OI és un factor desencadenant del fenomen en espanyol també l'ha apuntada Soler (1993: 66-67).

Tot i que no disposem d'un corpus igualment ampli del català per poder comparar el percentatge d'OI inanimats i d'OI animats/humans amb concordança i sense concordança, sí que podem apuntar que la idea que els inanimats tinguin força números de ser compatibles amb la manca de concordança és probablement vàlida també per al català, atès que també en aquesta llengua aquest tipus d'OI seran OI allunyats del prototipus. A continuació reproduïm diversos exemples que hem pogut recollir del fenomen li-per-els $[i]$ amb referents inanimats:

(33) Li llevem valor a les coses (parla espontània, valencià, home jove, Marina Alta)

(34) Aquesta catalogació dictada per la Directiva Marc de l'Aigua li $i_{[\mathrm{sg}]}$ proporciona als aqüífers de l'àmbit ${ }_{[\mathrm{pl]}}$ una certa protecció $i$ un procés de gestió descrit en la Directiva. (Pla de gestió i Pla especial de protecció del medi natural i del paisatge dels ENP de la Plana de Lleida, Generalitat de Catalunya, pg. 72)

(35) Llegint l'expressió emprada, «adoctrinament a les aules», i la importància que el diari $\boldsymbol{l i}_{[\mathrm{sg}]}$ donava als fets $_{[\mathrm{pl]}}$-destacant-ho en portada-es podia pensar en una exclusiva o investigació potent. (Mèdia.cat, Observatori critic dels mitjans, 16/12/2016)

podem fer-nos una idea de la importància que se $\boldsymbol{l}_{[\mathbf{s g ]}}$ donava als espais escènics $_{[\mathrm{pl]}}$ i a la seva construcció (Teatre popular romà: Comèdia, tite-

\footnotetext{
${ }^{11}$ Concretament, l'estudi de corpus esmentat conclou que un $82 \%$ dels OI inanimats presenten manca de concordança, mentre que el percentatge baixa a un $52 \%$ en el cas dels animats. L'autora encara va més enllà i estableix una diferència entre els inanimats abstractes (amb un $100 \%$ de casos de manca de concordança) i els inanimats concrets (amb un $79 \%$ de casos de manca de concordança). És a dir, si un OI a més de ser inanimat és abstracte, encara se situa més lluny del prototipus de la categoria, que sol ser concret i específic, i per això ha de ser rescatat mitjançant un clític datiu no concordant que aparegui com a afix verbal.
} 
lles, poesia priàpica i pantomima, d'Enric Garriga, Joan Pascual i Joan Rioné. Tarragona: Publicacions de la Universitat Rovira i Virgili, 2016, p. 18)

(37) "Experiència és el nom que tothom $\boldsymbol{l i}_{[\mathrm{sgl}}$ dóna als seus errors [pl] $_{\text {" Oscar }}$ Wilde (Butlletí del Col-legi de Censors Jurats de Comptes de Catalunya, maig 2017)

(38) “No perseguirem la família que té un pis parat per al fill, sinó a qui

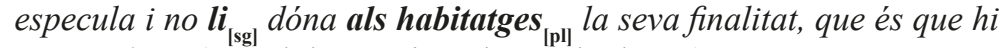
visqui algú" (Portal de notícies 3/24, 22/02/2016)

En el cas de l'espanyol, les diferències de freqüència del fenomen entre els OI animats/humans i els inanimats condueix Huerta Flores (2005) a considerar que el canvi devia començar (o si més no devia ser molt més preferible) en els OI inanimats, i que s'estengué posteriorment als humans. No sembla clar, però, que això es pugui exportar al cas català. De fet, com que bona part del català té el clític locatiu disponible, fa que sigui més difícil tractar com a datius determinats entitats inanimades. Així, per a molts parlants la duplicació de (35) no seria la primera opció, ni amb concordança ni sense, perquè als fets es tractaria com un complement locatiu (no datiu), que se substituiria pel clític hi: No hi donis tanta importància (, als fets). El mateix val per als exemples (36), (37) i (38). Amb això volem dir, doncs, que en el cas català, i a diferència de l'espanyol, el més probable és que la pèrdua de concordança comencés amb OI humans/animats i que, posteriorment, s'estengués cap a casos inanimats, en aquells dialectes (com el valencià o, també, el barceloní) on la duplicació de datiu no es restringeix als animats/humans, sinó que és possible amb exemples com els de més amunt (vg. la nota 4 i Pineda, 2016: § 2.2.1.1).

A banda de l'animacitat/humanitat, hi ha altres factors lexicosemàntics que condicionen el fenomen que estudiem. Per exemple, la distinció entre plurals amb la categoria de nombre més definida i plurals amb un sentit més unitari (Huerta Flores, 2005: 176). Així, en bona part dels exemples esmentats s'hi pot veure aquest sentit unitari de la pluralitat, referit a un grup d'entitats més genèric i indeterminat: els homes, els socialistes, els comuns, els nens, els pobres, els pardals... El fet que aquests plurals es refereixin a col·lectius es pot veure, doncs, com un factor que dissol l'especificitat del referent i provoca la necessitat de 
rescatar la prominència de l'OI mitjançant un clític no concordant que apareix com a afix verbal.

Huerta Flores (2007: 178) apunta encara un altre factor de degradació lexicosemàntica, que està relacionat de fet amb la distinció entre els predicats amb OI meta/receptor i els predicats amb OI experimentador que comentàvem anteriorment (subapartat 3.1). D'acord amb aquesta autora, la manca de concordança també pot ser propiciada si l'OI designa una entitat que experimenta un canvi d'estat sever, és a dir, un canvi que en degrada l'estatus com a entitat activa i volitiva. Si l'OI queda degradat, serà més possible que calgui recórrer a una marca o afix verbal (clític no concordant) en el verb que n'assenyali la presència i prominència. Aquesta afectació de l'OI, aquest canvi d'estat, es pot produir com a conseqüència de la transferència d'un objecte a l'espai físic de l'entitat designada per l'OI (en el cas de les construccions amb un OI meta que rep un OD, del tipus donar una cosa a algú) o bé pot tenir a veure amb un estímul sensorial que entra en l'espai intern de l'entitat designada per l'OI (quan s'expressa una transferència és perceptiva/ mental, com en dir alguna cosa a algú). La predicció és que aquests OI, afectats per l'esdeveniment descrit pel verb, siguin més susceptibles de desencadenar el fenomen. Efectivament, ja avançàvem al subapartat 3.1 d'aquesta secció que el fenomen del li-per-els [i] és molt abundant amb verbs d'aquest tipus.

Pensem que a aquests OI meta o receptors cal afegir-hi, també com a afectats i per tant propensos a presentar manca de concordança, els OI que designen el beneficiari d'un esdeveniment transitiu o el posseïdor de l'OD. N'hem trobat diversos exemples no concordants:

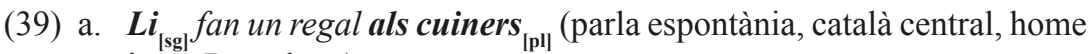
jove, Barcelona)

b. Li compro una rosa a totes les treballadores ${ }_{[\mathrm{pll}}$ (parla espontània, català central, home jove, Cardedeu)

c. El que no t'agrada que et facin a tu, tu no l'hi $\boldsymbol{~}_{[\mathrm{sg}]}$ facis als altres $\mathbf{[ p \mathrm { pl }}_{\mathrm{f}}$ (Ernest Folch, RAC1, 2017)

En canvi, els OI que són experimentadors són menys propensos a presentar la manca de concordança amb tanta freqüència: es tracta d'esdeveniments en els quals l'entitat designada per l'OI no pateix cap canvi d'estat sinó que simplement es troba en una situació estativa caracteritzada per una experiència psicològica/emocional (en el cas de les 
construccions amb verbs psicològics, com agradar una cosa a algú), o bé una experiència existencial (en el cas dels verbs inacusatius i existencials, com passar alguna cosa a algú o faltar alguna cosa a algú $)^{12}$. Al subapartat 3.1 vèiem que en català és possible trobar el fenomen li-per-els [i] amb aquest tipus de predicats (22)-(24), però constatàvem també que la major part d'exemples corresponien a verbs de l'altre tipus, com donar o dir.

Com ja dèiem llavors, pot semblar contradictori que justament els OI meta/receptors, que són els més prototípics, desencadenin amb més força el fenomen de la manca de concordança, però semblaria que el fet que siguin entitats més afectades contribueix a degradar un OI d'aquest tipus. Segons Huerta Flores (2005: 180), «se percibirá como una entidad dèbil y vulnerable, lo que supone un obstáculo en su codificación, pues crea problemes para que el OI mantenga su estatus como entidad activa y volitiva». És per això que caldrà recórrer a un clític no concordat, a manera d'afix verbal, que serveixi per senyalitzar i determinar la prominència de l'OI, altrament degradada. En el cas dels OI experimentadors, com que no pateixen cap afectació, mantenen el seu estatus d'objecte important i per tant poden prescindir més fàcilment de l'afix verbal en qüestió.

\subsection{Factors que causen degradació sintàctica}

L'OI queda degradat sintàcticament quan apareix amb altres constituents nuclears en la mateixa oració: així, s'ha constatat per a l'espanyol que l'OI, si coapareix amb un OD, és freqüent que perdi la concordança amb el clític duplicador, perquè «se produce una competencia argumental que provoca un debilitamiento categorial del OI que será restablecido mediante la pérdida de concordancia del clítico dativo», en el sentit que la presència d'un afix verbal en el verb anticiparà i realçarà la presència de l'OI en l'oració (Huerta Flores 2005: 172) ${ }^{13}$. La idea que la coaparició d'un OD i un OI genera una rivalitat d'arguments

\footnotetext{
${ }^{12}$ En l'estudi de corpus de l'espanyol mexicà de Huertas Flores (2005: 179), el percentatge d'OI receptors amb le-por-les és d'un 59\%, enfront d'un $45 \%$ en el cas dels OI experimentadors.

${ }^{13}$ En canvi, almenys per a l'espanyol, no sembla que la copresència de l'argument subjecte afecti (Huerta Flores 2005: 173, n. 11). Pensem que això es deu al fet que el subjecte de les construccions transitives és un argument extern, situat fora del sintagma verbal,
} 
pot desencadenar canvis en el datiu la defensa també Company (1998, 2002). ${ }^{14}$ Si l'OD i l'OI són presents en la mateixa oració, disminueix la prominència discursiva de l'OI, perquè hi ha una competència per esdevenir l'argument-objecte de l'oració (Huerta Flores, 2005: 181) ${ }^{15}$. Podem observar que la gran majoria dels exemples que hem proporcionat corresponen a oracions ditransitives, amb un OI i un OD. Sembla clar, doncs, que la degradació sintàctica de l'OI podria jugar un paper important també en el cas del català. Així mateix, els nostres informants ens han permès constatar que, amb estructures en què l'OI meta no va acompanyat de cap OD, com (40), la pèrdua de la concordança (37b) és marcadament més difícil:

(40) a. Aquest entrenador nou em sembla que no sap exigi'lzi (BCN) / exigir-los (VLC) als jugadors

b. "'Aquest entrenador nou em sembla que no sap exigir-li als jugadors

\subsection{Factors que causen degradació pragmàtica}

Des del punt de vista de la pragmàtica, l'OI pot quedar degradat si perd el seu caràcter topical. Així, a mesura que un $\mathrm{OI}$ es consideri menys central i menys vinculat a l'esdeveniment, la seva codificació serà menys clara, i la pèrdua de la concordança esdevindrà un mecanisme d'integració en l'oració mitjançant la presència del clític no concordat com a afix verbal que focalitza i avança la presència de l'OI i el destaca com a argument principal de l'oració. Es tracta, doncs, de reforçar el lligam

mentre que l'OD, situat dins el SV, és molt més pròxim a l'OI, situat també dins el SV (vg. l'estructura de (39)).

${ }^{14}$ No cal dir que si a aquesta convivència amb un OD s'hi suma algun dels altres factors esmentats que contribueixen a degradar la prototipicitat de l'OI, ens trobarem amb un OI encara més semblant a la categoria $O D$. Una manera de solucionar aquesta situació és que un dels dos arguments, l'OI, adquireixi una marcació per diferenciar-se, com és la pèrdua de la concordança perquè el clític esdevingui un afix verbal.

${ }^{15}$ En l'estudi de corpus de l'espanyol mexicà de Huertas Flores (2005: 181), els casos de le-por-les en estructures ditransitives són d'un $62 \%$, mentre que en estructures sense OD el percentatge és d'un $48 \%$. Cal dir que tots els exemples que dona l'autora per al recompte dels casos d'absència d'OD són de verbs ditransitius amb l'OD no expressat (del tipus Me niego a rentarles a mexicanos, o com el de (37b), és a dir, exemples amb un $\mathrm{OD}$ sobreentès o genèric), però no aclareix si tots els exemples usats per al recompte són d'aquest tipus o inclouen també construccions inacusatives (directament mancades d'OD, per definició) del tipus passar alguna cosa a algú, entre d'altres. 
de l'OI amb l'esdeveniment (Huerta Flores 2005: 183). Segons aquesta autora, seran no centrals, els OI que no participen en l'esdeveniment i que s'esmenten de manera secundària, com un afegitó en el context. En canvi, els OI més vinculats a l'esdeveniment ja són considerats prominents $i$ per tant no han de recórrer a la pèrdua de concordança per ser integrats en l'oració ${ }^{16}$. Hem de dir, però, que la classificació que fa aquesta autora dels diferents exemples del seu corpus de l'espanyol mexicà com a exponents d'OI centrals o no centrals (vg. Huerta Flores 2005: 184, exemples (7)) no és gaire clara al nostre entendre, i per això no entrem a considerar aquest tipus de degradació en relació amb els exemples catalans.

\subsection{Sintesi}

En aquesta secció hem fet una aproximació al fenomen li-per-els [i] a partir dels diversos condicionats i factors que s'han considerat rellevants per al sorgiment d'aquest fenomen en espanyol. Hem parlat de la necessitat que la duplicació de clític datiu sigui general perquè la pèrdua de concordança es pugui produir, i hem esmentat també el requisit de la posició postverbal de l'OI. A continuació, hem enumerat i exemplificat diversos factors que provoquen d'alguna manera la degradació de l'OI en el pla lexicosemàntic, sintàctic i pragmàtic ${ }^{17}$. Atesa aquesta degradació, es produeix una necessitat de restituir l'OI com a objec-

\footnotetext{
${ }^{16}$ En espanyol mexicà, per exemple, un $62 \%$ dels OI no centrals presenten pèrdua de concordança, mentre que el percentatge entre els OI centrals és lleugerament més baix, del $52 \%$, d'acord amb l'estudi de corpus de l'espanyol mexicà de Huerta Flores (2005: 183).

${ }^{17}$ A més, Huerta Flores (2005: 177) assenyala com un altre factor coadjuvador del fenomen l'expansió del sintagma OI, és a dir, el fet que aparegui amb adjectius, aposicions, oracions de relatiu, sintagmes preposicionals, etc. Si bé a priori aquests modificadors emfasitzen, especifiquen i desenvolupen la informació del nucli de l'OI, també poden «ocasionar dificultades en la codificación del OI debido a que el número de información proporcionada diluye la especficidad del referente», de manera que, almenys en l'estudi de corpus de l'espanyol mexicà d'aquesta autora, «la expansión representa un obstáculo para la clara y rápida identificación del OI», és a dir «a medida que expandemos un OI, éste se vera opacado por la información acumulada que lo modifica, de manera que la entidad ofrecerá más dificultades para una transparente y rápida codificación, pues se debilita la especificidad de quién es ese OI y de su número». En l'esmentat estudi de corpus de l'espanyol mexicà, un $76 \%$ dels OI amb expansió presenten manca de concordança, mentre que el percentatge baixa al $50 \%$ en el cas dels OI sense expansió.
} 
te prominent dins l'oració. Aquest rescat el proporciona el clític datiu, totalment despronominalitzat i mancat de concordança, que s'afixa el verb com una mera marca d'anticipació i realçament de l'OI present en l'estructura. En canvi, si no hi ha presència de factors degradadors, aquesta prominència 0 importància de l'OI resta intacta $i$ ja no caldrà obtenir cap reforç gramatical, és a dir, ja no caldrà recórrer a la pèrdua de concordança o, en altres paraules, a la creació d'una marcació de cas en el verb per obtenir un reforç gramatical.

És important remarcar que no tots els factors suara descrits tenen el mateix grau d'influència, i per descomptat no s'han pas de produir tots alhora perquè es desencadeni el fenomen: per exemple, són molts els exemples que hem citat aquí en què l'OI conserva plenament els trets [+humà], [+actiu], [+concret], [+volitiu], etc., és a dir, l'OI no està pas degradat des del punt de vista lexicosemàntic.

Finalment, és possible que en el cas del català valencià, un factor coadjuvant hagi estat el sincretisme entre el clític d'acusatiu (masculí) i de datiu en el plural, ambdós corresponents a els (vg., sobre els clítics en aquest dialecte, els treballs de Todolí $(1988,1992,1994)^{18}$. Aquesta possibilitat, que ens suggereix Josep Ribera (c.p.), pot haver estat sens dubte un element més en el cas dels parlars valencians, encara que caldria explicar per què el rebuig a la similitud acusatiu-datiu es produeix només quan el clític és duplicador, però no quan el clític té valor pronominal, cas en què el sincretisme entre els acusatiu (Els he vist) $\mathrm{i}$ els datiu (Els he dit que vinguen) no sembla pas gens conflictiu. Així mateix, aquest rebuig al sincretisme acusatiu/datiu tampoc no serviria per explicar per què el fenomen li-per-els[i] apareix també en altres zones del domini lingüístic, com el català central (i sobretot de l'àrea de Barcelona), on la distinció entre un clític acusatiu plural (els) i un clític datiu (elsi) és ben clara. Sigui com sigui, no hi ha dubte que el fenomen del li-per-els[i] és multicausal, de manera que no es pot descartar que

Les dades del català, però, no ens permeten ser conclusius sobre la rellevància d'aquest aspecte.

${ }^{18}$ Vegeu també Jiménez (1997: 367 i ss.) per a un tractament, en el marc de la teoria de l'optimitat, dels casos en què el clític acusatiu plural i el clític datiu plural coapareixen en una combinació. Ens interessa que, en parlars valencians com el de la Vila, la combinació els els s'evita, ja sigui eliminant la marca de plural del clític acusatiu [e(l)zo], ja sigui eliminant la marca de plural del clític datiu [liuz], punt de confluència amb el fenomen que tractem en aquest article. 
l'esmentat sincretisme hagi jugat un paper en el desenvolupament del canvi en els parlars valencians.

\section{Anàlisi formal}

\subsection{Els aplicatius}

En aquesta secció presentem l'anàlisi formal que permet donar compte, des del punt de vista estructural, de: (i) la presència d'un clític duplicador i d'un OI lèxic en el si d'una mateixa oració; i (ii) la pèrdua de concordança entre aquest clític duplicador i l'OI lèxic. Com ja hem avançat, seran un element clau els anomenats aplicatius. De fet, són molts els autors generativistes que darrerament han proposat que els OI en moltes llengües del món s'introdueixen en l'estructura mitjançant un nucli funcional anomenat aplicatiu. El terme aplicatiu té 1'origen en l'anàlisi de les llengües bantu, en les quals és força evident que els OI no són arguments directament dependents del verb, sinó arguments afegits, aplicats a l'estructura (per a una introducció més completa als aplicatius, vg. Pineda, 2016: $§ 2.1 .4 .1$ ).

La presència d'aquests nuclis en les llengües romàniques ha estat defensada per Cuervo (2003) per a l'espanyol, Diaconescu \& Rivero (2007) per al romanès, Fournier (2010) per al francès, Torres Morais \& Salles $(2010)$ per al portuguès i Pineda $(2013,2016)$ per al català, entre d'altres. A més, en les llengües que permeten la duplicació de clític dels OI, com l'espanyol, el romanès o el català, s'ha defensat que el clític és, justament, la realització (materialització) d'aquest nucli aplicatiu, com veurem tot seguit en (42) i (44).

El treball pioner de Pylkkänen (2002: 15) distingia l'existència en les llengües del món de dos tipus d'aplicatius, els baixos i els alts. Els primers, com veiem en (42), es combinen com a complement d'un verb i prenen al seu torn un SN/SD (l'OD) com a complement. Se situen, doncs, per sota del verb, i estableixen una relació de transferència de possessió entre l'argument que prenen com a complement (l'OD) i l'argument aplicat (l'OI), que se situa a l'especificador de l'aplicatiu. L'argument aplicat (OI) s'interpreta, doncs, com el receptor de l'OD. Corresponen a aquesta estructura els predicats ditransitius del tipus donar(-li) una cosa a algú, dir(-li) una cosa a algú. A partir de l'oració 
(41), exemplifiquem l'estructura dels aplicatius baixos en (42), prescindint dels detalls teòrics que ara no són rellevants:

(41) (Li) donarem un llibre a la Maria

(42) Aplicatiu baix

3

Subj SV

$\begin{array}{lllll}\text { V } & & & & \\ \text { SApl } & & & \\ \text { donar } & & & \\ & \text { OI } & & \text { Apl' } \\ \text { a la Maria } 3 & & \\ & \text { Apl } & \text { OD } & \\ & \text { (li) } & \text { un llibre }\end{array}$

Els aplicatius alts, en canvi, són legitimats estructuralment per sobre del verb, i prenen un SV com a complement, com veiem en (44). Així, serveixen per establir una relació semàntica entre l'argument aplicat (l'OI, situat en l'especificador de l'aplicatiu) i l'esdeveniment expressat pel SV. L'argument aplicat s'interpreta, en aquest cas, com el beneficiari, posseïdor o experimentador de tot l'esdeveniment expressat pel SV. Corresponen a aquesta estructura els predicats psicològics del tipus agradar, molestar, etc. així com els pseudoimpersonals del tipus passar, ocórrer. En (44) exemplifiquem l'estructura, despullada dels detalls teòrics ara innecessaris, corresponent a l'oració (43).

(43) A la Maria li agrada la xocolata

(44) Aplicatiu alt

$$
\begin{aligned}
& \text { SApl } \\
& 3 \\
& \text { OI Apl' } \\
& \text { A la Maria } 3 \\
& \text { Apl SV } \\
& \begin{array}{ll}
l i & 3 \\
& \mathrm{~V}
\end{array} \\
& \text { Subj } \\
& \text { agradar la xocolata }
\end{aligned}
$$


Ausín \& Fernández-Rubiera (2017: 103, 105) parteixen d'aquesta anàlisi basada en els nuclis aplicatius per explicar el fenomen del lepor-les de l'espanyol. En concret, defensen que en una oració com Les di los dibujos a los alumnos, amb concordança, el clític duplicador és la realització del que ells anomenen "morfema" aplicatiu i del morfema de concordança (54), mentre que en una oració com Le di los dibujos a los alumnos, sense concordança, el clític és la materialització de l'aplicatiu tot sol, sense el morfema de concordança (56). Aquests autors se centren, com es pot veure, en els exemples amb verbs com donar, és a dir, predicats de transferència de possessió en els quals l'aplicatiu és de tipus baix. Hem vist als subapartat 3.1 i 3.4 de la secció anterior que aquests predicats eren els que presentaven el fenomen amb més freqüència, i per això ara, a l'hora de dibuixar les representacions arbòries formals de les estructures, també ens hi centrarem. La idea bàsica, però, que el que varia és la presència o absència d'un nucli de concordança és vàlida, pensem, també per als aplicatius alts que poden presentar li-perels [i], com els que vèiem en (22)-(24).

L'assumpció teòrica que serveix de pilar a l'anàlisi d'Ausín \& Fernández-Rubiera és aplicar als clítics datius el mateix tractament que als clítics acusatius. I és que els clítics acusatius del tipus Et vaig veure a tu, L'estimo a ell han estat analitzats com a marcadors morfològics de concordança (Suñer 1988), semblants als morfemes de concordança de subjecte que veiem en les designacions verbals (cant-em). Ausín \& Fernández-Rubiera (2017: 109) adapten aquesta visió dels clítics acusatius als clítics datius: els clítics duplicadors acusatius (49) són morfemes de concordança, i els clítics duplicadors datius es descomponen en un morfema aplicatiu obligatori i un morfema de concordança opcional. Aquesta capa de concordança se situa en el nucli T(emps), que correspon a la flexió verbal, vg. p. ex. (54).

\subsection{El paral·lelisme entre els clítics acusatius i els clitics datius}

Hi ha diversos fets que fonamenten el paral·lelisme entre els clítics acusatius (corresponents a un morfema de concordança) i datius (corresponents a un aplicatiu i, opcionalment, un morfema de concordança). Com molt bé fan notar Ausín \& Fernández-Rubiera (2017: 106), els contextos en què la manca de concordança és rebutjada són els mateixos en què, si en comptes d'un OI tinguéssim un OD, la presència d'un 
clític acusatiu seria obligatòria. Vegem-ne un exemple. Hem vist al subapartat 3.3 que quan l'OI es troba en posició preverbal no es permet la pèrdua de concordança entre el clític datiu i l'OI (45). En aquest mateix context, si tinguéssim un OD preverbal (per tant, sinislocat), hauria de ser reprès obligatòriament per un clític (46). En canvi, això no és així quan l'OD apareix en posició postverbal (47), i justament és també la posició postverbal de l'OI la que permet la manca de concordança (48). En altres paraules, (47) i (48) tenen en comú que són contextos en què es prescindeix de la concordança: en el cas acusatiu, això vol dir que no hi haurà clític acusatiu, perquè els clítics acusatius són la realització del morfema de concordança (47); en el cas datiu, això vol dir que hi haurà un clític datiu no concordant, és a dir, un clític que realitza el nucli aplicatiu tot sol, sense el morfema de concordança (48):

* Als clients li vaig dir que tancariem.

(A) la Maria * (la) vaig veure ahir.

Vaig veure la Maria ahir.

Li vaig dir que tancaríem als clients.

Un altre paral $\cdot 1$ elisme que mostra que els contextos que no admeten el fenomen li-per-els [i] són els mateixos que requereixen la presència d'un clític acusatiu el trobem en el cas dels pronoms personals forts. Si un OD és un pronom fort el clític acusatiu és necessari (49) ${ }^{19}$, i si un OI és un pronom fort no permet la manca de concordança del clític duplicador $(50)^{20}$. És a dir, de nou, el que ocorre en ambdós casos és que no es pot prescindir de la concordança, de manera que hi ha d'haver un exponent que realitzi el morfema de concordança:

\footnotetext{
${ }^{19}$ En català, cal tenir en compte que la necessitat de duplicar els pronoms personals en funció d'OD és lleugerament diferent en els pronoms de 1a i 2a persona, d'una banda, i els de 3a persona, de l'altra (Todolí, 2002: §6.5.5.3a). Mentre que amb els primers el clític duplicador és obligatori, en els darrers hi ha variació, de manera en alguns dialectes, com el valencià, la duplicació hi serà igualment obligatòria, però en altres dialectes encara se'n pot prescindir:

(i) També (l') avisaran a ell.

${ }^{20}$ En el cas de l'espanyol, Ausín \& Fernández Rubiera (2017: 107, n. 3) admeten que la agramaticalitat de *Juan le entregó un libro a ellos potser no és del tot contundent, i deixen aquesta porta oberta per a futures recerques. En aquest sentit, un revisor anònim ens apunta l'existència, en espanyol, d'exemples com Le digo a ellos que vengan.
} 
(49) *(Et) vaig veure a tu.

(50) * ${ }^{*} \mathrm{i} /{ }^{\text {ok}} \mathrm{Els}[\mathrm{i}]$ vaig dir que tancaríem a ells.

\subsection{Les estructures amb concordança $i$ sense}

Un cop introduïda la justificació del tractament dels clítics datius com a formes que són la materialització d'un morfema/nucli aplicatiu i d'un morfema de concordança, podem presentar les estructures que corresponen als casos de clítics datius concordants i als casos de clítics datius no concordants (li-per-els[i]). Adoptem, per al català, l'anàlisi que Ausín \& Fernández-Rubiera (2017) han proposat recentment per al le-porles de l'espanyol, atès que per a totes dues llengües ja es compta amb un bon gruix de treballs que han defensat el tractament dels OI com a arguments introduïts per nuclis aplicatius i el tractament dels clítics datius duplicadors com a realitzacions dels esmentats nuclis aplicatius. A partir d'aquesta base, analitzar la pèrdua de concordança a partir de la descomposició dels clítics datius en un morfema/nucli aplicatiu i un morfema de concordança, com fan Ausín \& Fernández-Rubiera (2017), ens sembla, ara per ara, l'opció més raonable.

Així, modificant les estructures aplicatives que havíem presentat al subapartat 4.1, a l'oració (51) li correspon l'estructura de (52):

(51) Li donarem un llibre a la Maria

\section{ST}

3

Subj $\mathrm{T}$

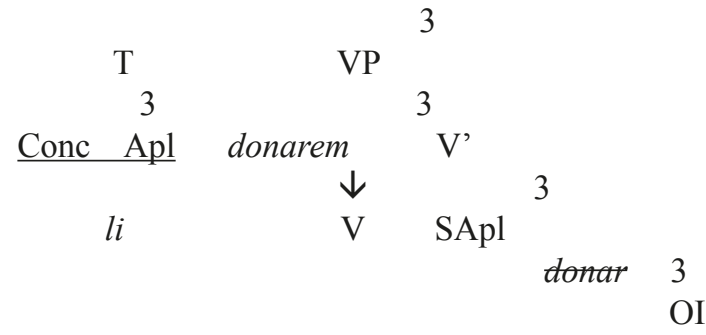

Apl'

a la Maria 3

$\begin{array}{ll}\text { Apl } & \text { OD } \\ l i & \text { un llibre }\end{array}$


Com vèiem en (50), quan l'OI és un pronom fort, el clític duplicador hi haurà de concordar. Ho tornem a veure en l'exemple plural de (53), representat en (54). En aquesta estructura, el clític datiu es genera en el nucli aplicatiu i, posteriorment, la presència del morfema de concordança a $\mathrm{T}$ fa que el clític datiu $l i$ generat en l'aplicatiu acabi esdevenint plural, els[i].

Els[i] / *Li donarem un llibre a ells

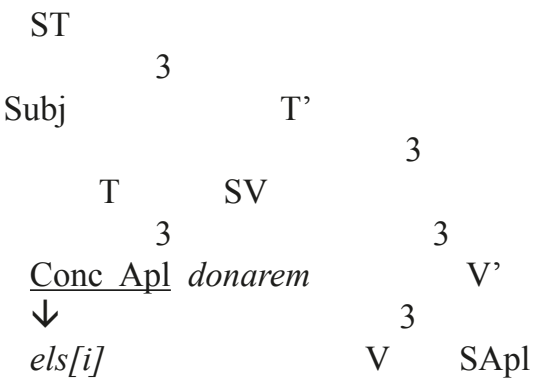

tonar 3

OI

Apl'

$$
\begin{array}{cl}
\text { a ells } 3 & \\
\text { Apl } & \text { OD } \\
\text { li } & \text { un llibre }
\end{array}
$$

Si, en canvi, l'OI no és pronominal, el morfema de concordança pot no ser-hi, la qual cosa possibilita el fenomen del li-per-els $[i]^{21}$ :

\footnotetext{
${ }^{21}$ Un revisor anònim fa notar que la diferència entre (54) i (56) pot semblar ad hoc, atesa la coincidència entre ambdues estructures. Certament, $i$ tenint en compte l'existència d'exemples com l'apuntat a la nota anterior, és possible que calgui replantejar el contrast entre aquestes dues estructures.
} 
Li donarem un llibre als clients

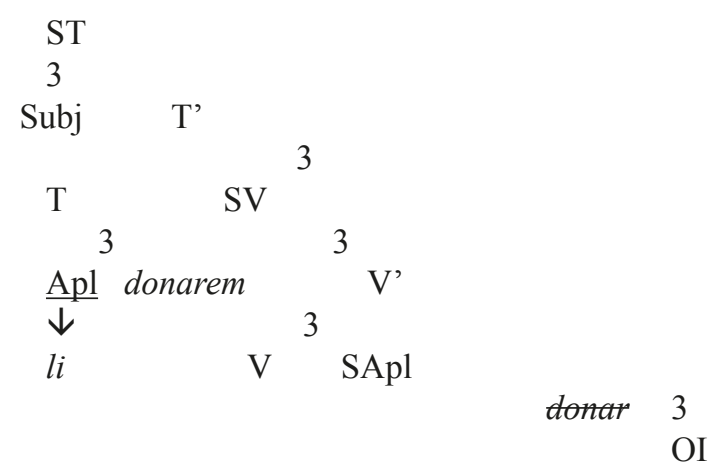

Apl'

$$
\begin{aligned}
\text { als clients } 3 & \\
\text { Apl } & \text { OD } \\
l i & \text { un llibre }
\end{aligned}
$$

En els casos en què la concordança amb l'OI plural es manté, del tipus Els[i] donarem el llibre a ells, la representació seria la mateixa que hem vist en (54).

Finalment, quan l'OI apareix en posició preverbal, es pot explicar la impossibilitat de li-per-els [i] si s'assumeix que aquest OI es genera en una posició situada fora del SV (Alexiadou, 2006), mentre que dins del SV el que hi ha és un element pronominal. Si el que tenim dins el SV en la posició d'OI és un pronom, ens trobem, doncs, davant d'un cas paral·lel al dels OI pronominals (53)-(54), amb els quals el li-perels $[i]$ tampoc era possible. D'acord amb Ausín \& Fernández-Rubiera (2017: 114), es tracta d'una configuració que desencadena la presència d'un morfema de concordança, el qual és responsable de l'aparició d'un clític acusatiu en els casos del tipus A ella la saludarem demà, A mi no $m$ 'ha vist i d'un clític datiu concordant en els casos que ens ocupen. 


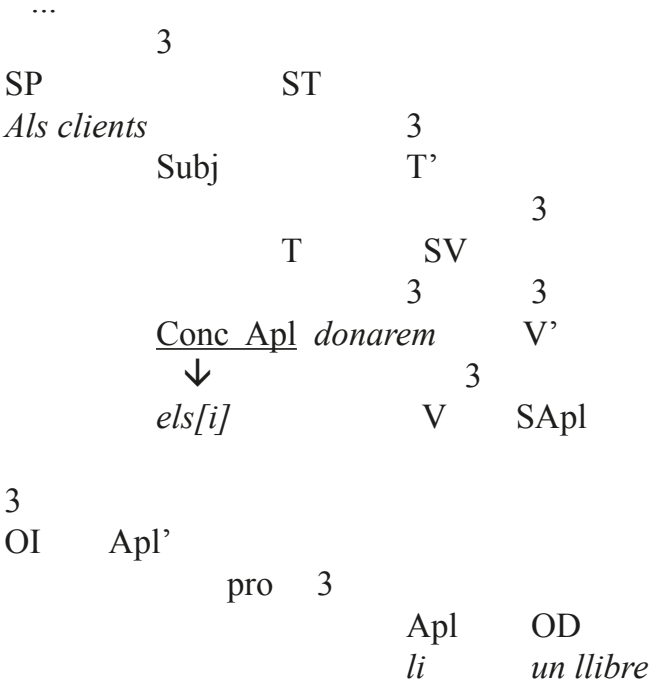

\section{Conclusions}

En aquest article hem volgut fer una primera aproximació al fenomen que hem convingut a anomenar li-per-els [i], consistent en la pèrdua de concordança entre el clític duplicador datiu i un OI lèxic plural. Es tracta, doncs, de l'ús incipient però ja força freqüent del clític $l i$ allà on esperaríem el clític plural elsi en català central o els en valencià.

Hem parlat inicialment de la duplicació de clític datiu, atès que es tracta d'un pas previ necessari per al sorgiment del fenomen que ens ocupa. A continuació, hem procurat analitzar amb cura els factors condicionants i desencadenants d'aquest canvi en català, tals com l'ordre de mots o les propietats lexicosemàntiques de l'OI, entre d'altres. Si en la generalització de la duplicació de datiu apuntàvem que el contacte amb l'espanyol molt probablement hi ha tingut un pes important, també en la pèrdua de concordança entre el clític i l'element duplicat la pressió d'aquesta llengua s'ha de considerar un condicionant fonamental. Amb tot, cal no perdre de vista que segurament en l'avenç d'aquests fenòmens en català hi ha també un component propi de l'evolució interna de la llengua. Ja hem vist que la sistematització de la duplicació de datiu es troba en diversos punts de la Romània, i hem vist també que 
la pèrdua de concordança és, en el fons, un pas ulterior "esperable" un cop el clític apareix sistemàticament.

Finalment, hem presentat una anàlisi formal a partir dels nuclis aplicatius que permet donar compte de la duplicació de datiu i de la manca de concordança. En definitiva, i tot esperant un estudi més aprofundit que parteixi d'un bon corpus que permeti extreure generalitzacions més contundents, hem mirat d'oferir un retrat d'un fenomen de la llengua catalana del qual, que ens consti, encara no s'havia parlat. Si hi ha alguna conclusió clara és que es tracta d'un fenomen sens dubte polièdric.

\section{Referències}

Alcina, Juan \& Blecua, José Manuel. 1975. Gramática española. Barcelona: Ariel.

Alexiadou, Artemis. 2006. Left dislocation (including CLLD). A Everaert, Martin \& van Riemdsijk, Henk (ed.) The Blackwell Companion to Syntax. Malden: Blackwell, 668-699.

Ausín, Adolfo \& Fernández-Rubiera, José Francisco. 2017. Laísmo and "lefor-les". A Perpiñán, Silvia; Heap, David; Moreno-Villamar, Itziri \& Soto-Corominas, Adriana (ed.) Romance Languages and Linguistic Theory 11: Selected papers from the 44th Linguistic Symposium on Romance Languages (LSRL). Amsterdam/Philadelphia: John Benjamins, 101-125.

Bel, Aurora. 2002. Les funcions sintàctiques. A Solà, Joan; Lloret, MariaRosa; Mascaró, Joan \& Pérez Saldanya, Manuel (ed.) Gramàtica del català contemporani. Barcelona: Empúries, vol. 2, 1077-1129.

Bresnan, Joan \& Mchombo, Sam A. 1987. Topic, pronoun and agreement in Chichewa. Language 63(4): 741- 782.

Casares, Julio. 1918. Crítica efimera. Madrid: Sturnino Calleja S.A.

Company, Concepción. 1992. La frase sustantiva en el español medieval. Cuatro cambios sintácticos. México: UNAM, 143-168.

Company, Concepción. 1998. The interplay between form and meaning in language change. Grammaticalization of cannibalistic datives in Spanish. Studies in Language 22(3), 529-566.

Company, Concepción. 2002. Reanálisis en cadena y gramaticalitzación. Dativos problemáticos en la historia del español. Verba. Anuario Galego de Filoloxía 29: 31-69.

Company, Concepción. 2003. Transitivity and grammaticalization of object. The struggle of direct and indirect object in Spanish. A Fiorentino, Giuliana (ed.) Transitivity in Romance Languages. Berlin / New York: Mouton de Gruyter, 217-260. 
Cuervo, Rufino José. 1907/1955. Apuntaciones críticas sobre el lenguaje bogotano, con frecuente referencia al de los paises de Hispano-América. Bogotá: Instituto Caro y Cuervo.

Cuervo, María Cristina. 2003. Datives at large (Tesi Doctoral). MIT.

Fernández Ramírez, Salvador. 1987. El pronombre. A Polo, José (ed.) Gramática española. Madrid: Arco Libros, §3.2.

Fernández-Soriano, Olga. 1999. El pronombre personal. Formas y distribuciones. Pronombres átonos y tónicos. A Bosque, Ignacio \& Demonte, Violeta (ed.) Gramática descriptiva de la lengua española. Madrid: Espasa-Calpe, 1209-1274.

Flórez, Luis. 1967. Temas de Castellano. Notas de divulgación. Bogotá: Instituto Caro y Cuervo.

Huerta Flores, Norohella. 2005. Gramaticalización y concordancia objetiva en el español: Despronominalización del clítico dativo plural. Verba 32: 165-190.

Jiménez, Jesús. 1997. L'estructura sil·làbica del dialecte valencià (Tesi Doctoral). Universitat de València.

Langacker, Ronald. 1991. Concept, Image and Symbol. The Cognitive Basis of Grammar. Berlin / New York: Mouton de Gruyter.

Pineda, Anna. 2013. Double object constructions in Spanish (and Catalan) revisited. A Baauw, Sergio; Drijkoningen, Frank; Meroni, Luisa \& Pinto, Manuela (ed.) Romance Languages and Linguistic Theory 2011. Amsterdam: John Benjamins, 193-216.

Pineda, Anna. 2016. Les fronteres de la (in)transitivitat. Estudi dels aplicatius en llengües romàniques $i$ basc. Barcelona: Institut d'Estudis Món Juïc. Col·lecció Cum Laude, 6.

Pylkkänen, Liina. 2002. Introducing arguments (Tesi Doctoral). MIT. [També Pylkkänen, Liina. 2008. Introducing arguments. Cambridge: The MIT Press.

Ribera, Josep. 2019. Els pronoms clitics de datiu plural en català antic. Evolució diacrònica i estat de la qüestió entre els segles XV i XVI. Estudis Romànics 41: 117-145.

Rigau, Gemma. 1980. Entorn de la naturalesa anafòrica dels pronoms personals en català. Els Marges 16: 93-98.

Solà, Joan. 1994. Sintaxi normativa: Estat de la qüestió. Barcelona: Empúries.

Soler, M. Ángeles. 1992. Le/Les > Le con duplicación de objeto indirecto y sin ella. Estudios de Lingüistica Aplicada 15/16: 57-68.

Sturgis, Cony. 1927. Uso de le por les. Hispania 10(4): 251-254.

Suñer, Margarita. 1988. The Role of Agreement in Clitic Doubled Constructions. Natural Language and Linguistic Theory 6(3): 391-434. 
Todolí, Júlia. 1988. Estat actual de la combinació binària de pronoms febles al País Valencià (Tesina de màster). Universitat de València.

Todolí, Júlia. 1992. Variants dels pronoms febles de 3a persona al País Valencià: regles fonosintàctiques i morfològiques. Zeitschrift für Katalanistik 5: 137-160.

Todolí, Júlia. 1994. Els clítics pronominals de 3a persona a les comarques d'Alacant: interferència lingüística del castellà? Actes del IXè Col·loqui Internacional de Llengua i Literatura Catalanes. Barcelona: Publicacions de l'Abadia de Montserrat, vol. 3, 197-209.

Todolí, Júlia. 2002. Els pronoms. A Solà, Joan; Lloret, Maria-Rosa; Mascaró, Joan \& Pérez Saldanya, Manuel (ed.) Gramàtica del català contemporani. Barcelona: Empúries, vol. 2, 1337-1433.

Urrutia Cárdenas, Hernán. 2003. Los clíticos de tercera persona en el País Vasco. Cauce 26: 517-538.

Vallduví, Enric. 2008. L'oració com a unitat informativa. A Solà, Joan; Lloret, Maria-Rosa; Mascaró, Joan \& Pérez Saldanya, Manuel (ed.) Gramàtica del català contemporani. Barcelona: Empúries, vol. 2, 1221-1279. 
